\title{
PREPARATION AND CHARACTERIZATION OF PHOSPHATE-SLUDGE KAOLIN MIXTURE FOR CERAMICS BRICKS
}

\author{
Jackson Muliawan $^{1,2}$, Sotya Astutiningsih ${ }^{1 *}$ \\ ${ }^{1}$ Department of Metallurgy \& Materials Engineering, Faculty of Engineering, Universitas Indonesia, \\ Kampus UI, Depok 16424, Indonesia \\ ${ }^{2}$ PT. Dutakimia Berjaya, Komplek Industri Cikupa Mas, Tangerang, Banten 15710, Indonesia
}

(Received: December 2017 / Revised: January 2018 / Accepted: February 2018)

\begin{abstract}
Phosphate Sludge (PS) waste has been a problem in metal surface finishing industry. The waste cannot be dumped in landfill due to the metal content. Valorisation of the waste will be beneficial in a way that it conserves natural reserves and reduces energy consumption. This paper describes the attempt of utilization of PS by mixing it in kaolin in preparation of ceramic bricks. A series of experiments showed that mixtures containing between 25-50 mass \% PS sintered at $1200^{\circ} \mathrm{C}$ attained the highest compressive strength of $>25 \mathrm{MPa}$. X-ray diffractions (XRD) showed that the presence of PS hindered the formation of mullite, the phase that contribute to strength in $\mathrm{Al}_{2} \mathrm{O}_{3}-\mathrm{SiO}_{2}$ kaolin system. In the mixture of 1:1 kaolin: PS fired at $1200^{\circ} \mathrm{C}$, cristobalite was formed, instead of mullite, as observed in the XRD patterns.
\end{abstract}

Keywords: Ceramics; Firing; Kaolin; Phosphate-sludge

\section{INTRODUCTION}

Zinc phosphate is widely used in the finishing process of metal industries such as automotive, steel furniture, houseware, electrical equipment, construction, etc., due to its capability to protect the base metal from corrosion and to enhance paint adhesion. However, the use of zinc phosphate produces waste in the form of liquid, which can be treated and disposed to the environment, and solid sediment known as phosphate sludge (PS) which is harmful if not properly treated. PS is a mixture of iron and zinc salt of phosphoric acid with the general formula $\mathrm{ZnFe}_{7 / 3}\left(\mathrm{PO}_{4}\right)_{3}$, also called as phosphophylite. PS mass range consists mainly of, in weight percentage, $\sim 20$ iron, 50-55 phosphorus, and $\sim 10$ zinc (Narayanan, 2005). According to the US Environmental Agency (USEPA) PS is considered hazardous and therefore must be encapsulated before disposing in landfills. The high cost of PS handling that cannot be disposed into drains and the environment directly, has been a problem that demands an urgent solution.

Effort to recover PS involved leaching and extraction processes in physics and chemistry or solidification (Kuo, 2012; Navarro-Blasco et al., 2015). Reuse and recycling of the materials was focused on the recovery of zinc, iron and phosphate. Several methods for reclaiming phosphate has been patented (Narayanan, 2005), however none can be claimed to be the most effective method in terms of benefits versus energy consumption or cost. Utilization of this solid waste into building materials becomes an alternative to recovery. Unlike the ordinary building materials, the capability of, especially hazardous, metals containment within the method used is of prime important. Some of use of PS reported were as an aggregate for

\footnotetext{
*Corresponding author's email: sotya.astutiningsih@ui.ac.id, Tel: +62-21-786-3510, Fax: +62-21-787-2350

Permalink/DOI: https://doi.org/10.14716/ijtech.v9i2.1119
} 
concrete (Doğan \& Karpuzcu, 2010; Loutou et al., 2013); as an ingredient in the manufacture of clinker in cement industry (Caponero \&Tenório, 2000; Lin et al., 2009); and in clay bricks manufacture (Bersch et al., 2012).

The presence of phosphate and iron oxides affects sintering temperature hence phase(s) formation, mechanical and physical properties of the products. A study found that the addition of phosphate compounds into kaolin decreased sintering temperature of up to $200^{\circ} \mathrm{C}$ without decreasing rupture strength (Little et al., 2008). Little and colleagues reported an experiment by adding 10 weight $\%$ of dried PS of tri-cationic phosphate solution into fly ash ceramic, resulted in significantly lower sintering temperature of up to $75^{\circ} \mathrm{C}$ (Little et al., 2008). Besides lowering the sintering temperature, the addition of PS also reduced the level of arsenic leaching (Little et al., 2008). In addition, the presence of a metal with a low melting point such as zinc, contributed to the increase of liquid phase at lower temperatures (Little et al., 2008). PS could also be added by 10-20 weight \% in concrete for applications that do not requires high strength (Ucaroglu \& Talinli, 2012). The presence of iron oxides in kaolin lowers the sintering temperature of up to $50^{\circ} \mathrm{C}$ (Nana et al., 2013) and resulted in solidified phase of mullite and cristobalite (Little et al., 2008). It was also found that mullite crystal in lath-like and needlelike shape occurred in samples containing iron oxide (Guo, 2010). Flexural strength of samples with a high content of iron oxide found to be higher than the samples with a low content of iron oxide (Michot et al., 2008).

In this work, kaolin- based ceramic brick with the addition of PS has been prepared and characterized. The mass optimization of PS utilization is the main focus in this study. Sintering temperature related to optimum mixture composition of PS-kaolin was varied to obtain the best compressive strength at the lowest sintering temperatures, hence the minimum energy consumption.

\section{METHODOLOGY}

\subsection{Raw Materials}

PS used in these experiments were supplied from a metal surface treatment company in Banten Province, Indonesia, while kaolin was purchased from PT RAK Minerals Indonesia under the trademark of Cerafill. The kaolin, with a size of 325 mesh, was originated from Bangka island, Indonesia. Chemical compositions, analysed using $\mathrm{X}$ ray fluorescence spectroscopy, of both raw materials are presented in Table 1 and 2.

\subsection{Specimens Preparation}

PS was cloth-filtered to reduce excessive water, washed and then dried at $110^{\circ} \mathrm{C}$ until sufficiently dried to be milled. The milled PS was mashed by hand mortar and sieved to 100 mesh. PS and kaolin at specified mixing ratios were mixed using hand rotating drum and casted in molds with dimensions according to the tests. After casting, the specimens were dried in an oven at $110^{\circ} \mathrm{C}$ for at least 24 hours. Cubes of $50 \times 50 \times 50 \mathrm{~mm}^{3}$ were prepared for compression test. Compressive strength values presented were from three best specimens. For each composition and sintering condition, materials from broken compression test samples were taken for x-ray diffraction and scanning electron microscopy (SEM). Variations of composition, sintering temperature and sintering time were performed to obtain optimum compressive strength with minimum of energy consumption, i.e. the lowest sintering temperature and time. Sintering was conducted in an electric furnace with a heating rate of $5^{\circ} \mathrm{C} / \mathrm{min}$ to $500^{\circ} \mathrm{C}$, at $10^{\circ} \mathrm{C} / \mathrm{min}$ from 500 to $925^{\circ} \mathrm{C}$ and at $15^{\circ} \mathrm{C} / \mathrm{min}$ from $925^{\circ} \mathrm{C}$ to the specified sintering temperature. 
Table 1 Chemical composition of phosphate sludge

\begin{tabular}{lrcr}
\hline Compound & Mass (\%) & Element & Mass (\%) \\
\hline $\mathrm{Al}_{2} \mathrm{O}_{3}$ & 0.11 & $\mathrm{Al}$ & 0.06 \\
$\mathrm{Fe}_{2} \mathrm{O}_{3}$ & 29.39 & $\mathrm{Fe}$ & 20.56 \\
$\mathrm{Na}_{2} \mathrm{O}$ & 1.82 & $\mathrm{Na}$ & 1.35 \\
$\mathrm{P}_{2} \mathrm{O}_{5}$ & 38.83 & $\mathrm{P}$ & 16.94 \\
$\mathrm{LOI}$ & 23.70 & - & - \\
$\mathrm{ZnO}$ & 5.64 & $\mathrm{Zn}$ & 4.53 \\
\hline
\end{tabular}

Table 2 Chemical composition of kaolin

\begin{tabular}{cr}
\hline Compound/element & Mass (\%) \\
\hline $\mathrm{Al}_{2} \mathrm{O}_{3}$ & 42.3029 \\
$\mathrm{SiO}_{2}$ & 55.1546 \\
$\mathrm{~S}$ & - \\
$\mathrm{K}_{2} \mathrm{O}$ & 1.2419 \\
$\mathrm{CaO}$ & - \\
$\mathrm{TiO}_{2}$ & 0.2068 \\
$\mathrm{MnO}$ & - \\
$\mathrm{Fe}_{2} \mathrm{O}_{3}$ & 1.0902 \\
$\mathrm{ZrO}_{2}$ & - \\
$\mathrm{V}_{2} \mathrm{O}_{3}$ & 0.0037 \\
\hline
\end{tabular}

\subsection{Characterization Techniques}

Phase analysis using XRD and SEM observation were carried out to understand the phase(s) formation during sintering. Density, water absorption and initial rate of suction (IRS) of the products with the optimum strength were then measured.

XRD was performed using XRD-7000 X Shimadzu Maxima, equipped with a graphite monochromator and using $\mathrm{Cu}$ radiation $\mathrm{K} \alpha$, wavelength $(\lambda)$ of $1.54 \AA$. JEOL JSM-6390A SEM equipped with Energy-Dispersive X-ray Spectroscopy (EDS) was utilized for microstructure observation. Density of the specimen was calculated by dividing the mass measured with volume calculated from the specimen dimension. Dimensional measurements were carried out using a calliper while mass of the specimens were weighed using an analytical balance with an accuracy of \pm 0.01 gram. Water absorption was calculated using Equation 1 as follows,

$$
\% \text { absorption }=\left\{100\left(w_{s}-w_{d}\right)\right\} / w
$$

where $w_{s}$ counts for saturated mass after soaked in cold water for 24 hours, and $w_{d}$ is dry mass of specimen before soaking.

Initial Rate of Suction (IRS) was calculated using Equation 2 as follows,

$$
I R S=\left(m_{1}-m_{2}\right) K
$$

where IRS is for initial rate of suction in gr/minute/30in ${ }^{2}$ or in $\mathrm{gr} /$ minute/193.55 $\mathrm{cm}^{2}$, in which $\mathrm{K}=30 /$ Area or $\mathrm{K}=193.55 /$ Area, respectively. 


\section{RESULTS AND DISCUSSION}

\subsection{Compressive Strength}

Figure 1 shows the compressive strength of kaolin - PS at various compositions after firing at different temperature and time. Compressive strength values presented were from the best three specimens made at the specified firing condition. Many specimens cracked during firing very probably due to thermal shrinkage. At all compositions, strength increased with increasing firing temperature, however the increase in strength up to $1000^{\circ} \mathrm{C}$ was not significant. Significant increase occurrred at firing above $1150^{\circ} \mathrm{C}$. Accordingly, $1200^{\circ} \mathrm{C}$ can be considered as a minimum sintering temperature to produce ceramic bricks complying with the required compressive strength of more than $10 \mathrm{MPa}$.

Figure 2 shows the compressive strength of 2 hours $-1200^{\circ} \mathrm{C}$ sintered kaolin with $0,10,20,25$ and 50 mass \% substitution of PS. As shown by the figure, there was a tendency that strength increased with the addition of PS up to $25 \%$ after which the strength decreased. However the strength of kaolin without PS was inconsistently lower compared to the same treatment at 1 hour firing as shown in Figure 1. Highest compressive strength of $>25 \mathrm{MPa}$ was achieved by specimens prepared with the addition of 25 to $50 \%$ of PS fired at $1200^{\circ} \mathrm{C}$.

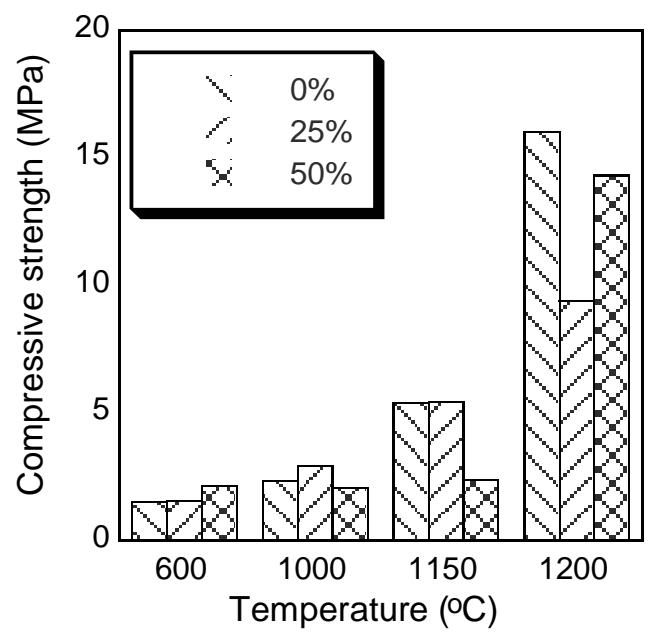

Figure 1 Compressive strength of 0, 25 and 50 mass \% PS - kaolin specimens fired at different temperatures for 1 hour sintering

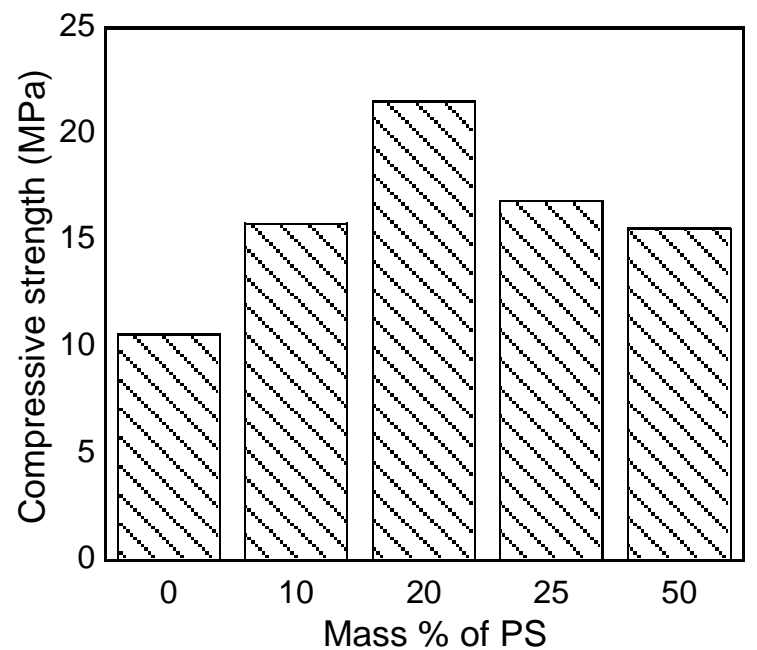

Figure 2 Compressive strength of kaolin - PS specimens fired at $1200^{\circ} \mathrm{C}$ for 2 hours with different content of PS in mass percent 


\subsection{Microstructures}

Figure 3 shows the fractured surface of $1200^{\circ} \mathrm{C}$ - fired specimens of PS-kaolin containing 0, 10, 20 and 50\% PS. These SEM images were at the same magnification and it shows that specimens with higher content of PS contains more pores. Specimens' surface topography at 0 mass \% PS, as shown in Figure 3a appeared denser and did not show any pores. Specimen with $10 \%$ PS already showed a few pores, in the image in Figure $3 b$ there were approximately 4 small pores sizing less than $10 \mu \mathrm{m}$. Increased addition of PS to $20 \%$ in which the specimen's surface image shown in Figure $3 \mathrm{c}$ showed much more pores with diameter ranging from 10 to $100 \mu \mathrm{m}$. In the clay-PS mixture of $50 \%$ as presented in Figure 3d, the specimen was full of large cavities and started to disintegrate. Previous study on PS-fly ash mixture found that PS addition into fly ash specimens resulted in larger cavities than without PS addition, moreover, specimens containing PS experienced bloating (Little et al., 2008). Increased voids size of the specimen can be caused by lower melting point compounds like $\mathrm{Zn}\left(\mathrm{PO}_{3}\right)_{2}, \mathrm{Zn}_{3}\left(\mathrm{PO}_{4}\right)_{2}, \mathrm{ZnP}_{4}$ and the reduction of $\mathrm{Fe}_{2} \mathrm{O}_{3}$ into $\mathrm{Fe}_{3} \mathrm{O}_{4}$ at temperatures $>1000^{\circ} \mathrm{C}$ producing $\mathrm{O}_{2}$ gas which was then trapped in the specimens. Porosity in the specimens can lead to higher water absorption. On the other hand, another study found that the addition of $10 \% \mathrm{H}_{3} \mathrm{PO}_{4}$ into kaolin significantly lowered porosity (Charfi et al., 2013).
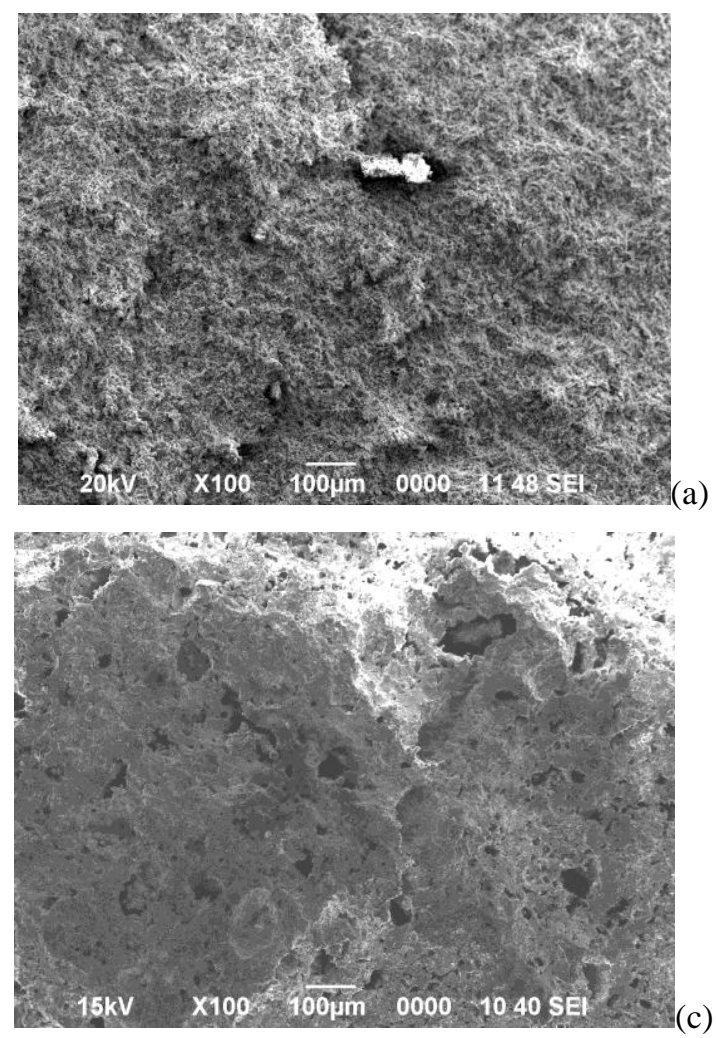
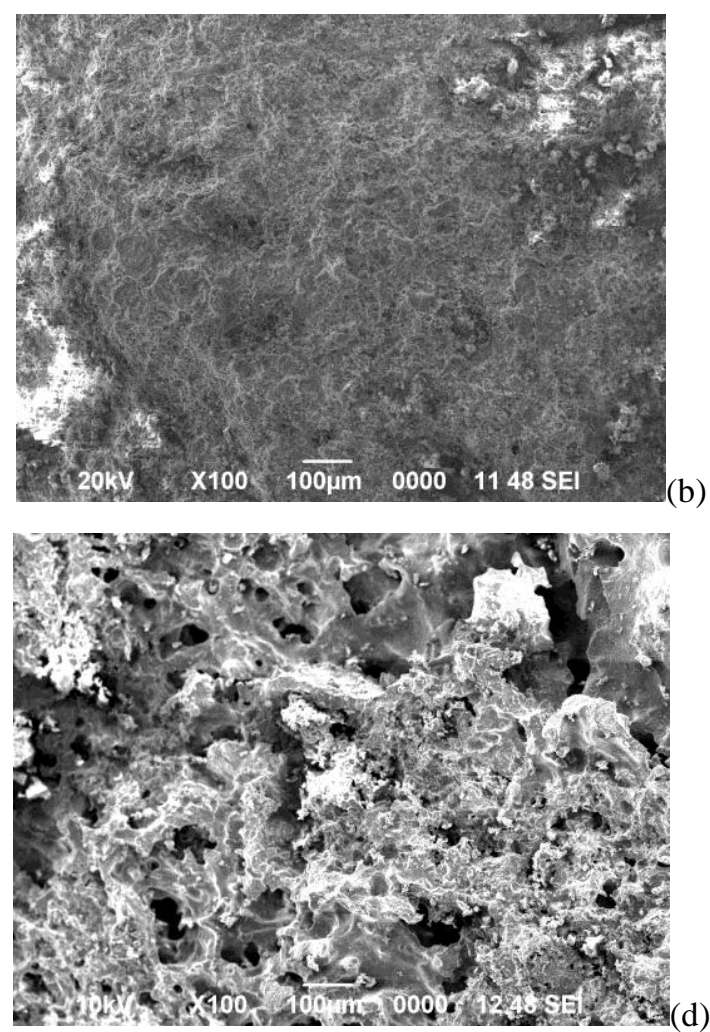

Figure 3 SEM micrographs of PS-kaolin specimens fired at $1200^{\circ} \mathrm{C}$ for 2 hours: (a) $0 \%$ PS; (b) $10 \%$ PS; (c) $20 \%$ PS; (d) $50 \%$ PS

\subsection{X-ray Diffraction}

Heating the mixture of 1:1 PS-kaolin, or $50 \%$ PS, by weight at elevated temperature of 1150 and $1200^{\circ} \mathrm{C}$ induced the formation of $\beta$ cristobalite, a metastable phase formed during cooling of silica, shown on the XRD pattern in Figure 4. Previous study on kaolinite showed that cristobalite was formed at $1050^{\circ} \mathrm{C}$ following the formation of mullite starting at $950^{\circ} \mathrm{C}$ (Michot et al., 2008). The expected formation of mullite in the 1:1 PS-kaolin system could not be fulfilled in these experiments. Mullite, a synthetic phase formed upon firing, is desirable in 
ceramic system of $\mathrm{Al}_{2} \mathrm{O}_{3}-\mathrm{SiO}_{2}$ due to its contribution to high mechanical properties. In the kaolin system alone, mullite was formed upon firing at $1200^{\circ} \mathrm{C}$ as confirmed by the XRD pattern presented in Figure 5. Mullite was however formed together with cristobalite, at the presence of PS up to $20 \%$ as shown by the XRD pattern in Figure 5. Phases formation in this system agreed with Little and colleagues (Little et al., 2008). The presence of cristobalite in the system was an indication of melting of silica and hence it can be suggested that the strength developed in the the mixture of high PS content was contributed by the formation of low melting glass, rather than mullite, that bound the particles together. It could also explained that the strength of kaolin with PS addition is lower than pure kaolin system.

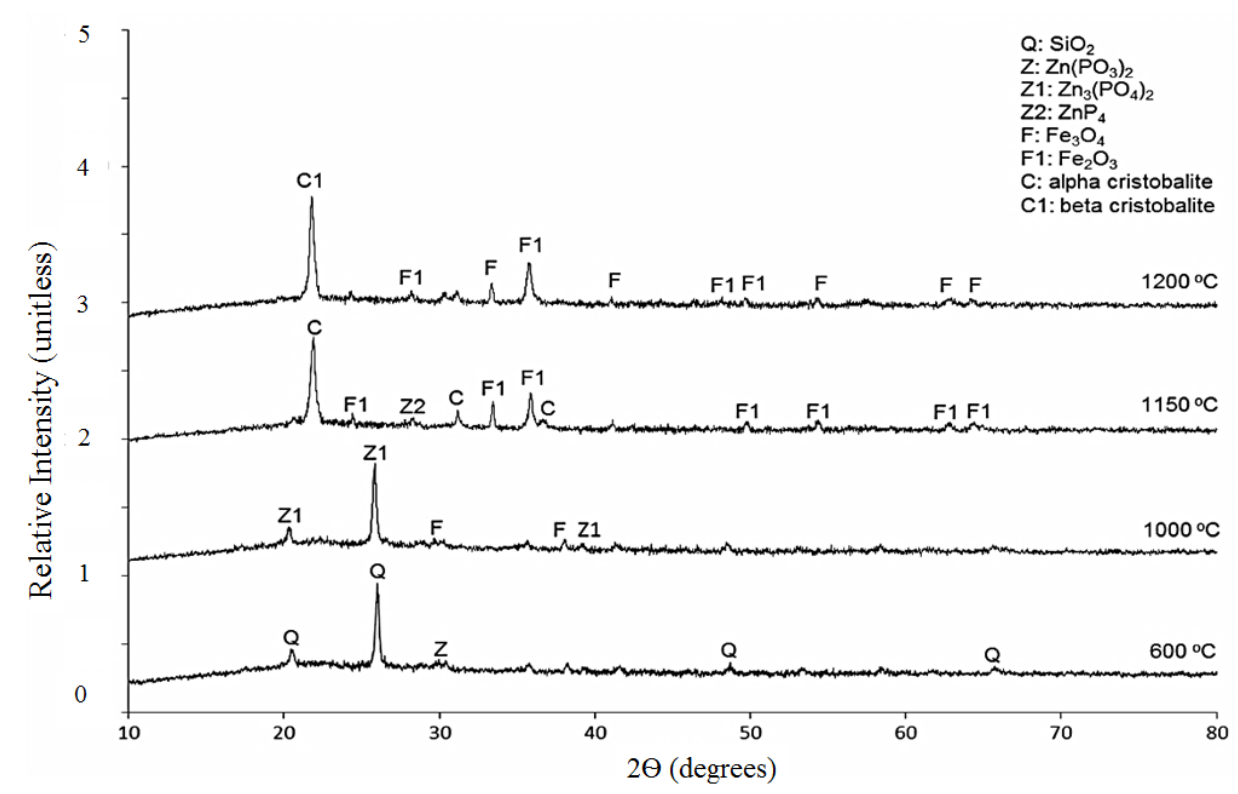

Figure 4 Plot of intensity in counts versus $2 \theta$ angle showing The XRD patterns of 1:1 PS - kaolin mixture by mass fired at different temperatures

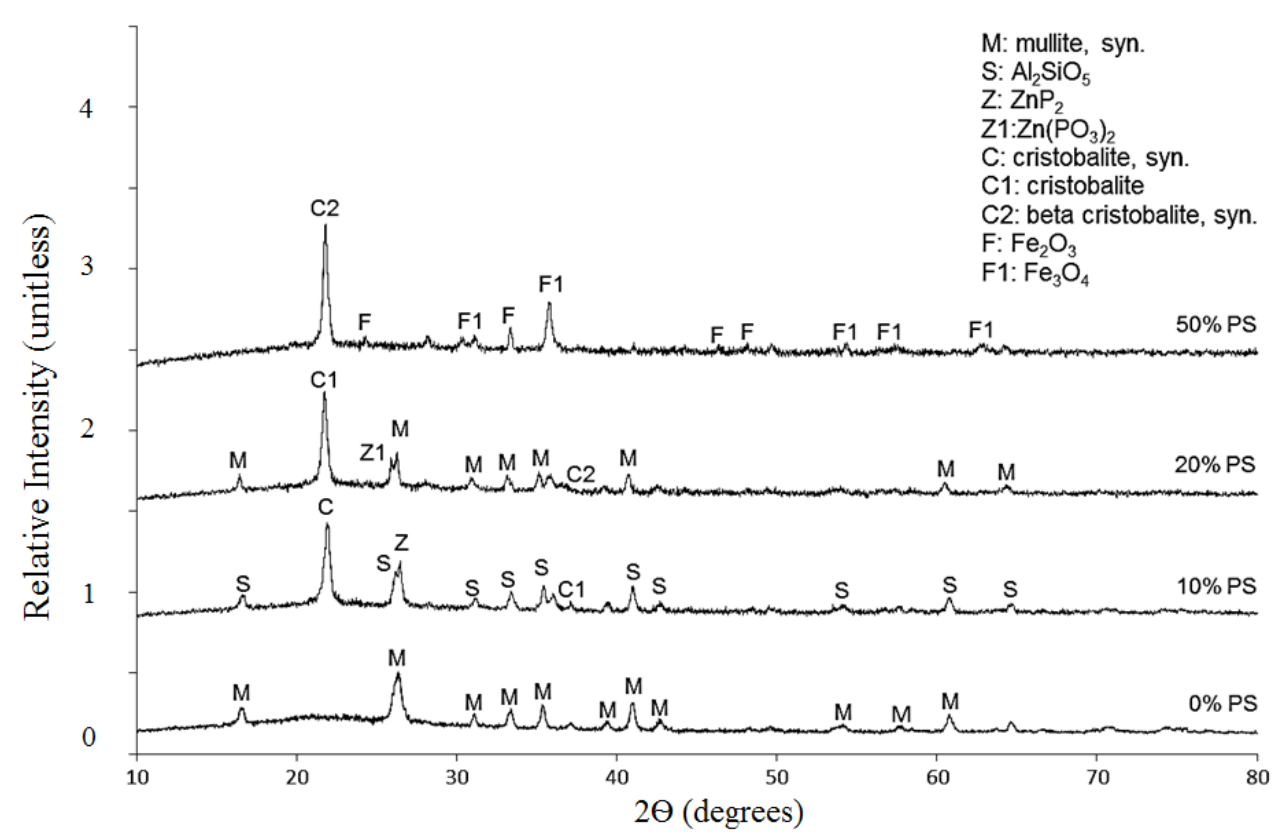

Figure 5 Plot of intensity in counts versus two theta angle XRD patterns of kaolin mixture specimens with various content of $\mathrm{PS}$ fired at $1200^{\circ} \mathrm{C}$ for 2 hours. $\mathrm{M}=\mathrm{S}=$ mullite or $\mathrm{Al}_{2} \mathrm{SiO}_{5}$ 


\subsection{Water Absorption and Initial Rate of Suction (IRS)}

Mean value of water absorption of specimens containing 10 mass $\%$ PS fired at $1200^{\circ} \mathrm{C}$ was $30.23 \%$ which is not in accordance with ASTM C 67-03 "Standard test method for sampling and testing bricks and structural clay tile" which is 13 to $17 \%$. The higher value of water absorption was associated to voids caused by the presence of PS in kaolin mixture as demonstrated by the SEM observation presented in Figure 3. Due to similar reason with water absorption, the IRS of kaolin mixture containing 10 weight\% of PS did not meet the required value of $<20 \mathrm{~g} / \mathrm{dm}^{2} / \mathrm{min}$. IRS measurement were performed on 11 samples and gave the mean value of $239 \mathrm{~g} / \mathrm{dm}^{2} / \mathrm{min}$.

\section{CONCLUSION}

The fact that many of the specimens cracked and the results of compressive strength suggested that PS - kaolin mixture specimens were sensitive to heating/firing parameters. Before firing at high temperatures, the specimens should be dried, and the firing cycle should be carefully controlled to avoid shrinkage. Based on the experiment results, highest compressive strength of $>25 \mathrm{MPa}$ was achieved by specimens prepared with the addition of 25 to $50 \%$ of PS fired at $1200^{\circ} \mathrm{C}$. The melting of silica was believed to occurred in kaolin - PS mixture and that the melt binding the particles together was the mechanism of strength development. The addition of PS in kaolin induced porosity. SEM observation showed that pore size within the specimens increased with PS. The porosity was believed to be the cause of high values of water absorption and IRS which was below the standard.

\section{ACKNOWLEDGEMENT}

This research has been funded by The Ministry of Research and Higher Education of the Republic of Indonesia through The University of Indonesia under the grant Excellent Research of Higher Education (Penelitian Unggulan Perguruan Tinggi) 2017 No. 2760/ADD/UN2.R3.1/HKP05.00/2017. The authors wish to thank the Laboratory of Metallurgical Process of the Department of Metallurgy and Materials for facilitating the experiments.

\section{REFERENCES}

Bersch, R.A., Brehm, F.A., Kazmierczak, C.S., 2012. Changes in Ceramic Blocks Porosity with Phosphate Sludge due to Salt Crystallization. University of Vale do Rio dos Sinos, Brazil

Caponero, J., Tenório, J.A.S., 2000. Laboratory Testing of the Use of Phosphate-coating Sludge in Cement Clinker. Resources, Conservation and Recycling, Volume 29(3), pp. 169-179

Charfi, A., Sahnoun, R.D., Bouaziz, J., 2013. Characterization and Mechanical Properties of Phosphate-kaolin Clay. Laboratory of Industrial Chemistry, University of Sfax. Tunisia

Doğan, Ö., Karpuzcu, M., 2010. Recovery of Phosphate Sludge as Concrete Supplementary Materials. Clean-Soil, Air, Water, Volume 38(10), pp. 977-980

Guo, A., 2010. Preparation of Mullite from Desilication-fly Ash. Fuel, Volume 89(12), pp. 3630-3636

Kuo, Y-M., 2012. An Alternative Approach to Recovering Valuable Metals from Zinc Phosphating Sludge. Journal of Hazardous Materials, Volume 201-202, pp. 265-272

Lin, K-L., Lin, D.F., Luo, H.L., 2009. Influence of Phosphate of the Waste Sludge on the Hydration Characteristics of Eco-cement. Journal of Hazardous Materials, Volume 168(23), pp. 1105-1110

Little, M.R., Adell, V., Boccaccini, A.R., Cheeseman, C.R., 2008. Production of Novel Ceramic Materials from Coal Fly Ash and Metal Finishing Wastes. Resources Conservation Recycling, Volume 52(11), pp. 1329-1335 
Loutou, M., Hajjaji, M., Mansori, M., Favotto, C., Hakkou, R., 2013. Phosphate Sludge: Thermal Transformation and Use as Lightweight Aggregate Materials. Journal of Environmental Management, Volume 130, pp. 354-360

Michot, A., Smith, D.S., Degot, S., Gault, C., 2008. Thermal Conductivity and Specific Heat of Kaolinite: Evolution with Thermal Treatment. Journal of the European Ceramic Society, Volume 28(14), pp. 2639-2644

Nana, G.L., Bonnet, J.P., Soro, N., 2013. Influence of Iron on the Structural Reorganization Process during the Firing of Kaolin. Journal of the European Ceramic Society, Volume 33, pp. 661-668

Narayanan, T.S.N.S., 2005. Surface Pretreatment by Phosphate Conversion Coating - A Review. Reviews on Advanced Materials Science, Volume 9(2), pp. 130-177

Navarro-Blasco, I., Duran, A., Perez-Niccolas, M., Fernandez, J.M., Sierra, R., Alares, J.I. 2015. A Safer Disposal of Hazardous Waste Phosphate Coating Sludge by Formation of an Amorphous Calcium Phosphate Matrix. Journal of Environmental Management, Volume 159, pp. 288-300

Ucaroglu, S., Talinli I., 2012. Recovery and Safer Disposal of Phosphate Coating Sludge by Solidification/Stabilisation. Journal of Environmental Management, Volume 105, pp. 131137 